\title{
Shifts in value chain governance and upgrading in the European periphery of automotive production: evidence from Bursa, Turkey
}

\author{
Güldem Özatağan \\ Department of City and Regional Planning, Faculty of Architecture, Izmir Institute of \\ Technology, Gülbahce Köyü, Urla, Izmir, Turkey; e-mail: guldemozatagan@iyte.edu.tr, \\ gozattagan@yahoo.com
}

Received 16 September; in revised form 30 November 2010

\begin{abstract}
This paper examines shifts in value chain governance and upgrading in the automotive component production node of Bursa in Turkey. Component suppliers in Bursa have gained design and product-development competences, one result of which is that European and global firms have turned to the creation of modular value chains for the sourcing of components from these suppliers. This paper considers the implications of the insertion of Turkish suppliers into modular value chains on suppliers' upgrading, and reveals that, despite the diffusion of design and product-development competences to suppliers in Bursa, cutting-edge innovation activities such as marketing and branding continue to remain the domain of the lead firms. It is argued that although Turkish suppliers seem to be successful in upgrading to take on design and product-development tasks, this has been more due to the willingness of global lead firms to relinquish these functions than to the success of Turkish suppliers in encroaching upon these once core competences of their customers. It is concluded that power asymmetries in global automotive value chains continue to exist, and that lead firms continue to have a major influence on the type of upgrading strategies that are open to their suppliers.
\end{abstract}

\section{Introduction}

Since the 1990s automotive manufacturers have changed their strategies towards internationalisation and vertical disintegration, and have passed the responsibility for design and product development to their suppliers, providing very little support beyond design specifications (Sturgeon, 2002). This process has fuelled an expectation that these deeply capable suppliers will gain an independent stance vis-à-vis their customers (page 455), implying a potentially favourable opportunity for a more balanced relationship between the powerful automotive manufacturers and their relatively powerless component suppliers (Borrus et al, 2000; Follis et al, 2002; Humphrey and Memedovic, 2003; Humphrey et al, 2000; MacDuffie and Helper, 2005; Sadler, 1998; Shimokawa, 1999). Through direct participation in such chains, it has been suggested, component manufacturers in newly industrialising countries may be able to leverage design capabilities and upgrade by moving from manufacturing to component design (Sturgeon and Lester, 2004). Evidence of this can be observed in several high-performing newly industrialised Asian economies, such as Korea, Malaysia, Taiwan, Thailand, and China, where it is believed that in time such companies may develop capabilities in the conceptualisation, design, and manufacture of finished products under their own brands, allowing them to emerge as leading firms in their own right.

It would be fair to say, however, that industrial upgrading through involvement in global chains of automotive lead firms is not without problems. Although Western lead firms have increased their involvement in peripheral economies, their increasing reliance on large global suppliers based in the West to support their global operations has presented challenges to the upgrading paths pursued by some East Asian economies in the past (Sturgeon and Lester, 2004). There is evidence that many firms have retreated 
from the strategy of own-brand production to that of own-design manufacture or own-equipment manufacture, and that for many firms the upgrading path stops at the design phase (Sturgeon and Lester, 2004). What is more, in economies that have not performed as well as those mentioned above, many domestic firms have failed to establish such less asymmetrical relations since they do not possess the competencies required for such relations to develop (Humphrey and Schmiz, 2004; Sturgeon and Lester, 2004). It is evident that they have been generally locked in to low-end production, which requires limited competences in meeting the cost, flexibility, and quality requirements of their customers (Barnes and Kaplinsky, 2000; Evren, 2002; Humphrey, 2000; 2003a; Humphrey and Memedovic, 2003). It has also been suggested that the upgrading of capabilities by these manufacturers has become increasingly difficult due to the challenges presented to suppliers in developing economies by the rise of global lead firms (Sturgeon and Lester, 2004).

In this paper these assertions will be revisited through an investigation of the shifts in value chain governance and upgrading in Bursa, an automotive component production node in Turkey, which became integrated into the European and global automotive system after the 1990s. Building on the global value chain (GVC) typology suggested by Gereffi et al (2005), and a questionnaire survey of 103 component suppliers, it was observed that component suppliers in Bursa, have gained design and product-development competences and that, as a result of this, European and global lead firms have turned to the creation of modular value chains for sourcing from these suppliers. This point is important in that it conflicts with suggestions that the diffusion of design competencies is confined to the direct suppliers of vehicle manufacturers, or to some Asian suppliers which have moved up the automotive value chain (Steinfeld, 2004; Sturgeon and Lester, 2004; Takayasu and Mori, 2004), and that the possibility for the development of innovation capabilities in less favoured regions is less likely (Evren, 2002, page 299). Instead, evidence from Bursa suggests that the consequences of the current reorganisation of the automotive industry have resulted in a further diffusion of design competences among suppliers on the periphery of automotive production-as has been the case for some suppliers in Bursa.

This leads to the question of how this change in the distribution of power and, hence, shift in value chain governance, will affect the prospects of Turkish suppliers for upgrading. Providing an answer to this question is important, as current literature anticipates that less asymmetrical relationships lead to a move towards higher value-added activities (Humphrey, 2003b; Humphrey and Schmitz, 2002a; 2004; Schmitz, 2004). This assertion is tested in this paper through a quantitative analysis in which the different types of GVC governance observed in Bursa are compared in terms of differences in innovation activities associated with process, product, and functional upgrading. The results suggest that, although design and product-development responsibilities have been passed to suppliers in Bursa, leading-edge innovation activities, such as marketing and branding, have remained with the lead firms. It follows from this new evidence that the question of whether or not this development entails less asymmetrical relationships is a complicated subject, with further complexities encountered when attempting to define whether these suppliers have encroached upon the core competences of their customers. The case study provided in this paper indicates that the reorganisation of the automotive industry provided additional opportunities for Turkish suppliers, and allowed the diffusion of design and product-development capabilities-including some that had typically been controlled by lead firms. However, the results of the study also suggest that this responsibility has been passed on more due to the willingness of global lead firms to relinquish these functions in the ongoing reorganisation of the automotive industry than to the success of Turkish suppliers in 
encroaching upon the once core competences of their customers. Hence, it is argued in this paper that despite the increasing competences of Turkish suppliers, power asymmetries in the value chains of their lead firms continue to exist, and lead firms continue to have a major influence on the type of upgrading strategies that are open to their suppliers.

Before examining these findings in detail I first provide an overview of the reorganisation of the global supply industry, outlining the subsequent changes in the governance of the global automotive value chain, and then discuss the implications on supplier upgrading. I then draw on evidence from field research to explore how shifts in the governance of the global automotive value chain have impacted upon supplier upgrading in Bursa.

\section{Reorganisation of the global supply industry, changing power relations, and shifts in global value chain governance}

Since the late 1980s and 1990s the automotive industry has undergone a significant restructuring. Lead firms have decreased their degree of vertical integration, identifying and focusing on core competences such as product development, marketing, and other activities related to brand development, while outsourcing and transferring responsibility for a broad range of noncore activities to specialised suppliers. Since the late 1980s global leaders have been outsourcing their production activities, increasingly incorporating suppliers from many developing countries (Humphrey, 2003b; Sadler, 1999); and more recently, they have even turned over design and product-development tasks to specialised external suppliers (Humphrey and Memedovic, 2003; Sadler, 1998; 1999; Sturgeon and Lester, 2004). Their suppliers are expected to provide them with a number of related modules ${ }^{(1)}$ that are ready to be assembled on the production line, and they are expected to become responsible for the design of these modules. In this way, lead firms are able to change and improve components with ease (Camuffo, 2002) and outsource and/or relocate module design and production more easily (Sturgeon and Lester, 2004).

One of the most notable features of this organisational change has been the rise of full-service suppliers which are capable of designing complex modules and systems on the basis of the specific requirements of their assemblers using their own technologies, and of supplying them in globally dispersed geographies. While this has enabled lead firms to transfer product-development and design costs to component suppliers and take advantage of their specialised technological skills and competences (Humphrey, 2003a), it has undoubtedly also increased opportunities for component suppliers (Dicken, 2003). Yusuf (2004, page 11), for example, argues that full-service supply has provided opportunities for local East Asian suppliers to earn the higher profits which accrue from close longer-term relationships and the joint development of technology, and has forced them to double their efforts in building technological capabilities - or be squeezed out of the GVCs of lead firms (Yusuf, 2004, page 11). Dicken (2003, page 19) noted, however, that these opportunities have been "tempered by a clear and increasing preference by lead firms to work with a smaller number of suppliers". Since the 1990s the automotive industry has seen major consolidations, giving rise to global suppliers which have increased their technological competences and have expanded their global reach through the acquisition of competitors from across the world (Humphrey, 2000; Humphrey and Memedovic, 2003; MacDuffie and Helper, 2005; Sturgeon, 2002; 2003). These firms have become the preferred suppliers

(1) "Modules are units in a larger system that are structurally independent of one another, but work together" (Baldwin and Clark, 2000, page 63) to provide a specific function (Dicken, 2003). 
of lead firms, and are taking on greater responsibilities in component and module design and product development. A subsequent impact of this reorganisation has been the systematisation of the supply industry in tiers in terms of the division of labour, with distinct requirements of the suppliers in each tier (Humphrey and Memedovic, 2003).

This process of industrial organisation and the resulting emergence of new sets of actors imply that new forms of governance are required which will allow lead firms to coordinate their globally dispersed value chains. It also implies that customer - supplier relations in the automotive industry are all about power. Over the last few decades, the GVC perspective has emerged as a fruitful approach, which focuses on the asymmetrical power relationships between lead firms and their suppliers in producer-driven chains, such as the automotive industry (Barnes and Kaplinsky, 2000; Barnes et al, 2004; Humphrey, 2003a; Humphrey and Memedovic, 2003; Layan, 2000; Posthuma, 2005). 'Value-chain governance' reflects power asymmetries that arise due to the power of lead firms in global chains to coordinate what is to be produced, how it is to be produced, and how much will be produced (Dolan and Humphrey, 2000; Humphrey and Schmitz, 2000; 2002b).

The GVC literature has identified four types of relations that have been established to achieve coordination in GVCs, each of which is associated with different power asymmetries. In market-based chains the basis of the customer-supplier relationship is price information and specifications (Gereffi et al, 2005; Sturgeon, 2002). Suppliers produce a range of standard products which are available to a wide range of customers, and the selection of these suppliers is based on price-based competition (Humphrey, 2003b). In captive chains suppliers carry out specific tasks, following detailed instructions provided by their customers: the customers are responsible for product design (Dicken, 2003; Humphrey, 2003b). This means that the same part can be sourced from a number of different suppliers, who are awarded contracts based on price. Hence, in captive chains customer - supplier relations are asymmetrical: suppliers are subordinate to powerful lead firms who specify product and process characteristics, leaving them with little autonomy to develop relatively independent strategies and thus undertake activities requiring a higher skill content (see Humphrey, 2003a; Humphrey and Schmitz, 2000; 2002a; 2002b; Schmitz, 2004). Before the 1980s, interfirm relationships put in place to achieve coordination in the automotive value chain were characterised by captive, or market-based, relations. As production in the automotive industry has become more and more globally dispersed, supply chains have had to accommodate more sophisticated forms of coordination-especially in relation to the integration of components into the design of modules and systems; and in relation to quality standards, leading to more complex customer-supplier relationships, which persist over longer periods (Follis et al, 2002; MacDuffie and Helper, 2005; Sadler, 1998; Sturgeon et al, 2008). Now, lead firms and suppliers increasingly work together on the components for particular vehicles, and component suppliers are responsible not only for making the products according to the lead firms' specifications and delivering them in a timely fashion, but also for designing a solution, adapting a basic design to the customer's specific requirements, or designing a module or subsystem using their own technology. This implies a rise in importance of network-based value chains in the automotive industry - these can take two forms: relational and modular. Relational chains are characterised by more even relationships and build on complementary competences between the supplier and the customer, with the customer maintaining thick relations with suppliers who are involved in the design and product-development stages. 
Unlike relational chains, modular value chains $^{(2)}$ are characterised by a high degree of codifiable transfer of standards and specifications from lead firms to their various suppliers, who use identical or compatible production and technology systems; these chains thereby feature only loose and thin relational interactions (Gereffi et al, 2005; Sturgeon, 2002; Sturgeon and Lester, 2004). Modular value chains also necessitate the ability of suppliers to specify their own processes and use their own technology to manufacture components or modules according to the design specifications provided by lead firms. One other important aspect of a modular chain is the need for suppliers to be able to design a solution by adapting a basic design to the customers' specific requirements; or to design a module or subsystem using their own technology. Defined in this way, in modular chains competent suppliers have an independent status vis-à-vis their customers, which allows them to provide a wider range of services and have less dependence on the lead firm (Sturgeon, 2002; 2003).

Recently, Gereffi et al (2005) associated the types of value chain governance outlined above with combinations of three dimensions: the complexity of interfirm transactions; the ability to codify transactions; and the capabilities of suppliers (Gereffi et al, 2005). Combinations of these three variables locate the types of value chain governance between two extremes, ranging from nonexplicit coordination and power symmetry, to high explicit coordination and power asymmetry (table 1). The identification of the types of chain governance and the degree of power asymmetries associated with each type is important, as chain governance determines the extent to which a firm gains profits as they upgrade to assume responsibility for and control over more valueadded activities in the chain (Tokatlı and Kızlgün, 2004). This issue is addressed in section 3 .

Table 1. Types of global value chain governance (source: adapted from Gereffi et al (2005); survey data).

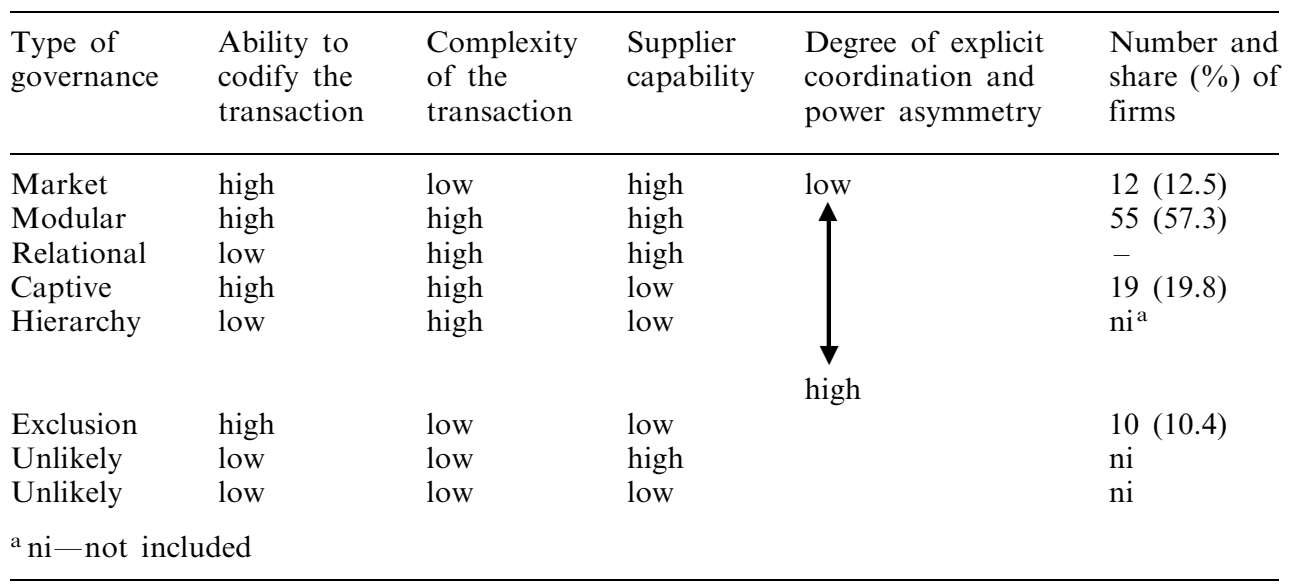

(2) A common use of the term 'modularity' refers to product architecture. Much of the discussion in relation to product modularity contains the idea that the product architecture of motor vehicles is modular, as it is in electronics. Others underline that the integral nature of product architecture in vehicles puts limits on modularity since it requires ensuring the compatibility of components and subsystems in order to make them work as a product when put together (Herrigel, 2004; Langlois and Robertson, 1992; Sako, 2002). It should be noted at this point that 'modularity' also encompasses 'value chain' and 'organisational' modularity (see Brusoni and Prencipe, 2001). A 'modular value chain' does not refer to a chain that depends on products having a modular product architecture but, as Humphrey and Schmitz (2004, page 377) explain, the term is used by GVC researchers "because of the analogy between a design that minimizes the customization of parts and the network that minimizes the customization of supplier-buyer relationships". 


\section{Value chain dynamics and upgrading}

In GVC terms the fact that the coordination of automotive value chains has required more collaborative, network-based relations between lead firms and competent suppliers has significant implications upon supplier upgrading. It suggests that, through direct participation in such chains, component manufacturers in newly industrialising countries could leverage design capabilities and move from manufacturing to component design (Sturgeon and Lester, 2004). According to Sturgeon (2002, page 483), being inserted into modular value chains is an important step in supplier upgrading, since in such chains supplier firms provide "services that require very little support or input-beyond design specifications from customer firms". Hence, by making the supplier an important part of the automotive value chain, the firm is put on a learning curve. This yields benefits beyond quality and flexibility, and forces the suppliers "to add entirely new competence areas, increasing the scope of activities while improving quality, delivery and cost performance" (page 455), implying that suppliers learn and upgrade beyond production. In the automotive industry, upgrading in production involves innovation oriented towards increasing the flexibility of production and the speed of the production process, improving the quality of products and production processes, and improving cost performance. It also includes the integration of various components of the automotive value chain through the use of highly automated and standardised technologies, and improving the efficiency of production and other activities by introducing new organisational methods. However, this does not bring as much profit as do product and functional upgrading as long as the related competences remain in the lead firms. Product upgrading involves moving into product lines with a higher unit value, and this is achieved by introducing new products, designs, or product-development processes. Improving through functional upgrading, that is, moving into higher value-added activities such as branding and marketing, is more difficult and requires the use of intangible assets rather than tangible ones (Tokatli and K1zılgün, 2004).

In the 1990s a few high-performing Asian economies, such as Korea, Malaysia, Taiwan, Thailand, and China, leveraged design capabilities, and consequently manufacturers have emerged which are capable of designing products for their customers - the branded manufacturers (Dicken, 2003; Sturgeon and Lester, 2004; Veloso and Kumar, 2002). It was anticipated that in time they would develop capabilities in conceptualising, designing, and manufacturing finished products under their own brand, which would eventually enable them to emerge as lead firms in their own right. However, functional upgrading, especially in the form of shifts from design-oriented activities to branding and marketing activities, and later to becoming lead firms in their own right, has proven to be difficult for many of these suppliers. Sturgeon and Lester (2004) noted that for many firms, the upgrading path stopped in the design phase for the simple reason that many firms retreated from the strategy of own-brand production to that of own design and production, the reason being that there was a reluctance to encroach upon the core competences of their customers.

For most of the suppliers in these countries, however, it was their failure to acquire the competences required for more collaborative relations to develop that halted their upgrade path (Humphrey and Schmitz, 2004; Sturgeon and Lester, 2004). For example, Takayasu and Mori (2004) noted that Thai firms had been slow to acquire the technology and design skills that would enable them to work more closely with assemblers and first-tier suppliers in R\&D and design. A similar situation exists in China where, as Steinfeld (2004) noted, most of the suppliers work with codified technologies to produce standardised commodities, with the minimum of design and R\&D inputs. 
The situation was even worse for less favoured regions on the periphery of automotive production. The lack of higher value-added competences had generally confined the vast majority of these suppliers to remain locked-in in captive value chains, in which the lead firms dictated the cost, flexibility, and quality requirements, while also collecting real rents (Humphrey, 2003a; Humphrey and Memedovic, 2003). The challenges presented by the rise of global lead firms also made it increasingly difficult for these suppliers to upgrade their capabilities to include design, produce development, marketing, and branding (Sturgeon and Lester, 2004). Evren (2002, page 299), for example, suggests that the Turkish automotive industry was "excluded from all the core activities such as design and product development" and argued that the possibility for the development of "smart activities and innovation in less favoured regions" was unlikely "unless parent firms change[d] their production and local sourcing strategies".

Since then, however, GVC research has established that power relations are not static but, rather, are constituted, transformed and reconstituted through asymmetrical and evolving power relations (Dicken et al, 2001, page 105), implying that the limits and barriers associated with specific modes of value chain governance might be temporary (Gereffi et al, 2005; Humphrey and Schmitz, 2002b; Ö̈zatağan, 2011; Sturgeon, 2009; Sturgeon et al, 2008; Tokatl1, 2007; 2008). This may be due to two factors. First, existing suppliers may acquire new capabilities, which may in turn decrease the need for global lead firms to maintain control over these suppliers. One major reason why lead firms establish asymmetric power relationships/tight coordination is to militate against the risk of supplier failure. As the competences of suppliers increase, lead firms may be more likely to vacate certain spaces, and chain governance can be expected to loosen (Humphrey and Schmitz, 2002a; 2002b).

Second, lead firms governing a specific value chain may be willing to relinquish some functions into which producers might move (Humphrey and Schmitz, 2002a). On this issue, recent evidence shows that manufacturers in the hierarchy of a supply chain have taken on new roles. For example, there have been increasing requests from second-tier suppliers for design expertise. Herrigel (2004), for example, shows that first-tier suppliers which are increasingly charged by vehicle assemblers with the responsibility for design and product development of increasingly complex modules and systems have faced difficulties in mastering design, technology, and manufacturing operations. By increasingly calling upon their suppliers to take on design responsibilities, while retaining overall control of the product-development process, they have sought to optimise their learning processes, minimise costs, and share the risks. Evidence from Fiat's Piedmontese auto-production system in Italy (Whitford and Enrietti, 2005) reinforces Herrigels findings: where requests from second-tier suppliers for design expertise have seen a marked increase. In addition, there is evidence that the pressure placed on higher tier suppliers to innovate has been passed down the automotive supply chain. Follis et al (2002), for example, show that lower tier suppliers have been put under pressure by their customers to innovate, and a substantial majority deliver on a just-in-time basis to their clients.

All of this recent evidence indicates that design and product development is less confined to the domain of direct suppliers to vehicle manufacturers, and that the increasingly standard practices observed in the higher tiers of the supply chain are being replicated at lower levels. This is an important development, as it indicates that the distribution of power in the automotive supply chain has changed, and hence implies a shift in value chain governance. What, then, are the consequences for supplier upgrading, and the diffusion of higher value-added competences from the top to further down the hierarchy of the supply chain? In this paper I aim to provide 
answers to these questions, but before that, in section 4 I look at the automotive industry in Bursa, and the dynamics of its integration into the European and global automotive systems since the 1990s. This is followed by a detailed investigation of the governance of the automotive value chain in Bursa.

\section{Empirical evidence}

\subsection{Bursa and its insertion into the European and global automotive system}

Bursa is a major automotive component-producing node in Turkey, the emergence of which dates back to the late 1960s when the manufacturing plants of Fiat and Renault were established there through joint ventures with the Turkish Tofas and Oyak Groups, and when KARSAN began automobile production under license from Peugeot. Like many manufacturing nodes elsewhere in the world, Bursa underwent a profound structural change after a gradual process of deregulation and trade liberalisation. This started with the export-oriented industrialisation strategy adopted in 1980, and continued throughout the 1990s and 2000s when suppliers were forced to compete internationally and adjust to the rapidly changing conditions of the global market (for details see Özatağan, 2011).

From a GVC perspective the major implication of this adjustment process was that suppliers could link-up with a diverse array of lead firms. First, the automotive sector witnessed a significant increase in foreign investments. New assembly-line investments were realised in Turkey, ${ }^{(3)}$ there were also significant increases in the shares of existing car manufacturers. ${ }^{(4)}$ These new assembly investments encouraged new foreign investments into the component industry; and in line with the global sourcing strategies of these assemblers, foreign component suppliers were either encouraged to take over the most successful suppliers or to establish greenfield investments. ${ }^{(5)}$ Second, domestic suppliers entered export markets, establishing ties with a variety of lead firms. The value of automotive exports from Bursa reached US $\$ 1.56$ billion in 2002, and more than doubled to reach US $\$ 3.65$ billion in 2006 (Undersecretariat of the Prime Ministry for Foreign Trade, 2007). Third, thanks to the Customs Union, the EU has become the major trade partner of suppliers both in Bursa and in Turkey as a whole in the automotive industry. Since 1995 the share of the value of Turkish automotive exports to EU countries has undergone a gradual increase: by the 2000s suppliers in Bursa and the rest of Turkey had achieved full-scale integration into the European regional automotive system. By $2003,73 \%$ of the US $\$ 6.5$ billion automotive exports of Turkey were oriented towards EU25 (KOSGEB, 2004).

The increasing role of global lead firms, coupled with Turkey's trade agreement with the EU, has had a significant impact on the supply industry in Bursa. There has been a significant rise in process standards and product quality. The assemblers and their lead firms which entered the Turkish market have developed models and product and process specifications, helped component manufacturers in the technology and organisation of production, and inspected the quality of their products and processes on-site. Suppliers in Bursa concentrated on the production process, with the lead firms retaining responsibility for product development and design. Gereffi (1999, page 53) attributes this process to 'organisational succession', which implies that the succession of lead firms permitted suppliers in Bursa to learn a great deal from global lead firms

(3) Of the seventeen vehicle assemblers in Turkey, eight had seen an increase in the share of foreign capital by 2007.

(4) By 2007 nine vehicle manufacturers had increased their share of foreign capital.

(5) The number of foreign component suppliers in Turkey increased from 138 in 1999 (Istanbul Sanayi Odas1, 2002) to 163 in 2005 (Undersecretariat of the Prime Ministry for Foreign Trade, 2005). 
on how to improve their production processes, raise quality standards, and increase the speed of response in meeting customer demands. In GVC terms, this implies that the lead firms employed captive modes of coordination in the supply of components from manufacturers in Bursa. Since then, however, there have been new developments in the organisation of automotive production. As explained in section 3, the global automotive industry has undergone much change since the 1990s, and this has been paralleled by changes in the nature of the interactions between the lead firms and their suppliers in Bursa. In the remainder of this paper I aim to unveil the impact of this transformation on suppliers on the periphery of automotive production, concentrating on the ways in which governance of the automotive value chain in Bursa has evolved, and on the implications of this evolution for supplier upgrading.

\subsection{Data}

The survey data were collected in the period December 2005-December 2006 by means of structured face-to-face interviews with the owners, managers, foreign-trade managers, or purchasing managers of 103 component suppliers in Bursa, with a response rate of $28 \%{ }^{(6)}$

The survey involved the gathering of information of two key types:

(a) firm specific: providing information on firms' innovative processes; and

(b) transaction specific: providing information on firms' customers and the nature of the interaction with their most important/main customer (the customer with the highest share in the firm's total sales).

The first dataset provided an understanding of the innovation activities associated with product, process, and functional upgrading (see appendix); the second set was used to develop a typology of value chain governance in line with the one suggested by Gereffi et al (2005). This was used to provide a systematic understanding of the ways in which the relationships between suppliers and their lead firms are coordinated, and to anticipate the ways in which the governance structures in the automotive value chain of Bursa have evolved. ${ }^{(7)}$ To this end, three dimensions of governance were identified.

1. The extent to which transactions are codified: based on the answer of the respondent to the question of to what extent the firm's main customer:

(a) specifies product and process characteristics and

(b) imposes quality and technical standards.

2. The complexity of the transaction: this was identified based on the answer of the respondent to the question of to what extent the firm's main customer takes part in:

(a) product and process development;

(b) upgrading technology; and

(c) training.

3. Supplier capability: this was identified based on the answer of the respondent to the question of to what extent the firm is engaged in:

(a) the definition of product characteristics, including:

- improving original designs and specifications and

- modifying and improving product features;

(6) For details of the collection of data and an overview of the general characteristics of suppliers in Bursa, see Özatağan (2011).

(7) Gereffi et al (2005, page 101) underline that "A high priority for the future will be the development of methods for measuring the key variables in the model [they suggested]. Effective proxies for transactional complexity, level of codification, and supplier competence must be identified and tested in the field"; their paper is one of the rare attempts to do this (for another, see Pietrobelli and Saliola, 2008). See also Sturgeon and Gereffi (2009), who suggest improved measures of industrial upgrading and technological learning in GVCs. 
(b) research and development activities:

- developing new products,

- developing new production processes/methods, and

- developing new designs.

In the survey, firms were requested to attribute a degree to each of the variables under each dimension in a three-point Likert-scale of: 'no', 'to some extent', and 'to a large extent'. A coefficient was assigned for each dimension, calculated as the sum of the points attributed to each variable under the relevant dimension, divided by the maximum possible score for each of the three dimensions (6 for the first dimension, 9 for the second, and 15 for the third dimension).

Cutting across these three dimensions, firms were classified on the basis of the value of the coefficients in each dimension as 'high', 'medium-high', 'medium', 'low', and 'no'. However, in order to overcome the problem of insufficient frequencies and complexity, the number of categories was reduced to two: 'low' or 'high'. Firms were then classified on the basis of their 'high' and 'low' positions for each of the three dimensions, which were then combined to yield eight possible types of value chain governance, reflecting different degrees of power asymmetry (see table 1). ${ }^{(8)}$

\subsection{Automotive value chain governance in Bursa}

Table 1 reveals some important results, indicating that supply chains require sophisticated forms of coordination, and subsequently that network-based value chains have become increasingly important in the automotive industry. This is evident first in the limited share $(10.4 \%)$ of the 'exclusion' governance type in Bursa, implying that it has become a requirement for suppliers to possess a minimum in certain competences if they are to be included in automotive value chains. This is also evident from the limited share of captive and market-based chains $(19.8 \%$ and $12.5 \%$, respectively). As mentioned above, as suppliers in the automotive industry are increasingly given responsibility for design and product development, investment in supplier relationships has become a requirement for such collaborations. Evidence from Bursa implies that in this context it has become increasingly difficult to maintain captive and marketbased relations (see MacDuffie and Helper, 2005; Sturgeon et al, 2008). Finally, it is evident from the significant share of network-based relations, that there are relatively more collaborative types of governance (which in the case of Bursa took the form of modular value chains $-57.3 \%$ ), characterised by working to the specifications of customers, sharing competences, and higher supplier capability in design and product development.

This is an important finding, in that it conflicts with the suggestion that the diffusion of design and product-development capabilities is an exception which is confined to direct suppliers of lead firms, or to a few, high-performing, Asian economies which have

${ }^{(8)}$ Of the eight outcomes, Gereffi et al (2005) treat the first five as modes of governance. In GVC terms, hierarchical chains reflect intrafirm trade between a transnational corporation and its subsidiaries. In this paper I treat each semiindependent subsidiary as an independent profit centre (see Dunford, 2009) and look at the interfirm relations of subsidiaries with their customers. This necessitates the type 'hierarchy' to be discarded. The type named 'exclusion' here represents a situation in which firms are likely to be excluded from the value chain due to their low capabilities - despite the low complexity of the transaction and the high ability to codify the transaction. Gereffi et al (2005) recognised the importance of this outcome, but did not consider it as a governance type in its own right; however, assuming that it may be a widespread outcome on the periphery of automotive production, in this paper I treat this as a type. The 'unlikely' outcomes represent combinations of low complexity of transactions and low ability to codify. These outcomes are excluded from further investigation with the assumption that the questionnaires were not successful (seven firms). In all, ninety-six supplier firms were found to be distributed among five types of value chain governance. 
been able to move up the value chain (Steinfeld, 2004; Sturgeon and Lester, 2004; Takayasu and Mori, 2004); and that the development of innovation capabilities among lower tier suppliers in less favoured regions is less likely (Evren, 2002; Humphrey and Schmitz, 2004). Instead, this new evidence from Bursa suggests a more widespread trend towards the diffusion of design competences in GVCs than has been suggested in previous literature - this also includes lower tier suppliers in other countries on the periphery of automotive production, like those in Turkey.

\subsection{Value-chain governance and supplier upgrading}

What, then, are the consequences for upgrading of increasing supplier competences and the subsequent shift in value chain governance in Bursa-from captive to modular value chains? In this section I attempt to answer this question by comparing the types of GVC governance observed in Bursa in terms of the differences in innovation activities associated with process, product, and functional upgrading.

This was done by applying an ANOVA test (see appendix for innovation variables used). The analysis did not provide significant results for the homogencity of variances test for innovation in technology systems, innovation in work systems, and process improvements (significance less than 0.05, see table 2). Because cell variances for these variables are unequal, interpretations rested on the figures from a Brown-Forsythe test as a substitute (table 3). The Brown - Forsythe test also did not provide significant results for innovation in technology systems. The results (table 4) indicate that a firm's innovativeness in the organisational system and in marketing and branding do not vary

Table 2. Type of global value chain governance and innovation: test of homogeneity of variances.

$\begin{array}{llll}\text { Levene } & \text { Degrees of } & \begin{array}{l}\text { Degrees of } \\ \text { fratistic }\end{array} & \text { Significance } \\ \text { freedom } 2 & \end{array}$

\begin{tabular}{lrrrl}
\hline Innovation in technology systems & 5.380 & 3 & 92 & 0.002 \\
Marketing and branding & 0.504 & 3 & 92 & 0.680 \\
$\begin{array}{l}\text { Design, product, and process } \\
\quad 1.650\end{array}$ & 3 & 92 & 0.183 \\
$\quad$ Innelopment & 6.887 & 3 & 92 & 0.000 \\
Innovation in work systems & 1.219 & 3 & 92 & 0.307 \\
Improvements in production process & 20.926 & 3 & 92 & 0.000 \\
\end{tabular}

Table 3. Type of global value chain governance and innovation: robust tests of equality of means.

$\begin{array}{lll}\text { Brown }- & \text { Degrees of } & \text { Degrees of } \\ \text { Forsythe } & \text { freedom } 1 & \text { freedom } 2\end{array}$

\begin{tabular}{lllll}
\hline Innovation in technology systems & 4.154 & 3 & 23.822 & 0.017 \\
Marketing and branding & 2.795 & 3 & 43.697 & 0.051 \\
$\begin{array}{l}\text { Design, product, and process } \\
\quad \text { development }\end{array}$ & 9.190 & 3 & 39.360 & 0.000 \\
Innovation in work systems & 2.573 & 3 & 27.046 & 0.075 \\
Innovation in organisational systems & 2.585 & 3 & 50.587 & 0.063 \\
Improvements in production process & na $^{\mathrm{c}}$ & na & na & na \\
a Asymptotically F-distributed. & & & \\
b Robust tests of equality of means cannot be performed for improvements in production \\
process because at least one group has 0 variance. \\
c na-not applicable.
\end{tabular}


Table 4. Type of global value chain governance and innovation: results of ANOVA.

\begin{tabular}{|c|c|c|c|c|c|c|}
\hline & & $\begin{array}{l}\text { Sum of } \\
\text { squares }\end{array}$ & $\begin{array}{l}\text { Degrees } \\
\text { of freedom }\end{array}$ & $\begin{array}{l}\text { Mean } \\
\text { square }\end{array}$ & $F$ & Significance \\
\hline $\begin{array}{l}\text { Innovation in technology } \\
\text { systems }\end{array}$ & $\begin{array}{l}\mathrm{BG}^{\mathrm{a}} \\
\mathrm{WG}^{\mathrm{b}} \\
\text { total }\end{array}$ & $\begin{array}{l}1.014 \\
5.107 \\
6.121\end{array}$ & $\begin{array}{r}3 \\
92 \\
95\end{array}$ & $\begin{array}{l}0.338 \\
0.056\end{array}$ & 6.091 & 0.001 \\
\hline Marketing and branding & $\begin{array}{l}\mathrm{BG} \\
\mathrm{WG} \\
\text { total }\end{array}$ & $\begin{array}{r}1.061 \\
12.811 \\
13.872\end{array}$ & $\begin{array}{r}3 \\
92 \\
95\end{array}$ & $\begin{array}{l}0.354 \\
0.139\end{array}$ & 2.539 & 0.061 \\
\hline $\begin{array}{l}\text { Design, product, and } \\
\text { process development }\end{array}$ & $\begin{array}{l}\mathrm{BG} \\
\mathrm{WG} \\
\text { total }\end{array}$ & $\begin{array}{r}2.810 \\
9.812 \\
12.622\end{array}$ & $\begin{array}{r}3 \\
92 \\
95\end{array}$ & $\begin{array}{l}0.937 \\
0.107\end{array}$ & 8.784 & 0.000 \\
\hline $\begin{array}{l}\text { Innovation in work } \\
\text { systems }\end{array}$ & $\begin{array}{l}\mathrm{BG} \\
\mathrm{WG} \\
\text { total }\end{array}$ & $\begin{array}{l}1.105 \\
7.704 \\
8.809\end{array}$ & $\begin{array}{r}3 \\
92 \\
95\end{array}$ & $\begin{array}{l}0.368 \\
0.084\end{array}$ & 4.400 & 0.006 \\
\hline $\begin{array}{l}\text { Innovation in } \\
\text { organisational systems }\end{array}$ & $\begin{array}{l}\mathrm{BG} \\
\mathrm{WG} \\
\text { total }\end{array}$ & $\begin{array}{r}0.937 \\
13.725 \\
14.662\end{array}$ & $\begin{array}{r}3 \\
92 \\
95\end{array}$ & $\begin{array}{l}0.312 \\
0.149\end{array}$ & 2.094 & 0.106 \\
\hline $\begin{array}{l}\text { Improvements in } \\
\text { production process }\end{array}$ & $\begin{array}{l}\mathrm{BG} \\
\mathrm{WG} \\
\text { total }\end{array}$ & $\begin{array}{l}0.299 \\
1.566 \\
1.865\end{array}$ & $\begin{array}{r}3 \\
92 \\
95\end{array}$ & $\begin{array}{l}0.100 \\
0.017\end{array}$ & 5.855 & 0.001 \\
\hline
\end{tabular}

Table 5. Type of global value chain (GVC) governance and innovativeness: results of post hoc least significant difference (LSD) test.

\begin{tabular}{|c|c|c|c|c|c|c|}
\hline \multirow[t]{2}{*}{ Type of innovation } & \multicolumn{6}{|c|}{ Type of GVC governance ${ }^{a}$} \\
\hline & I modular & II market & III captive & IV exclusion & $\begin{array}{l}\text { ANOVA } \\
\text { (signifi- } \\
\text { cance) }\end{array}$ & LSD test ${ }^{\mathrm{b}}$ \\
\hline $\begin{array}{l}\text { Innovation in } \\
\text { technology systems }{ }^{\mathrm{c}}\end{array}$ & 0.8839 & 0.7692 & 0.7976 & 0.5462 & 0.001 & \\
\hline Marketing and branding & 0.4364 & 0.5000 & 0.2368 & 0.2000 & 0.061 & \\
\hline $\begin{array}{l}\text { Design, product, and } \\
\text { process development }\end{array}$ & 0.6364 & 0.4167 & 0.2763 & 0.2250 & 0.000 & I $>$ II, III, IV \\
\hline $\begin{array}{l}\text { Innovation in work } \\
\text { systems }\end{array}$ & 1.1766 & 0.9643 & 1.0526 & 0.8714 & 0.006 & I > II, IV \\
\hline $\begin{array}{l}\text { Innovation in } \\
\text { organisational systems }\end{array}$ & 0.8273 & 0.5972 & 0.8684 & 0.6167 & 0.106 & \\
\hline $\begin{array}{l}\text { Improvements in } \\
\text { production process }\end{array}$ & 0.8273 & 0.5972 & 0.8684 & 0.6167 & 0.001 & I, II, III > IV \\
\hline
\end{tabular}

${ }^{a}$ Mean value per type of GVC governance.

b This test compares the means of all possible pairs of categories of 'GVC governance' and identifies particular pairs which show statistically significant mean differences. Here I provided information on the pairs of means which are statistically different (for example, the innovativeness of modular chains regarding design, product, and process development is significantly higher than chains governed by market-based, captive, and exclusion types of relations).

${ }^{c}$ The LSD test used for identifying significant mean differences between pairs of GVC governance types on innovation in technology systems is Tamhane's $T^{2}$, since for this variable the assumption of equal variances is not met. However, the Tamhane's $T^{2}$-statistic did not provide statistically significant differences between different pairs of GVC governance types. 
according to the type of GVC governance. In addition, they suggest that differences in a firm's innovativeness in 'design, product, and process development', 'work systems', and 'process improvements' can be attributed to the type of GVC governance into which the suppliers in Bursa are integrated.

In order to understand which differences are the most important and contribute most to the significant $F$-ratios for these differences, a post-hoc test (least significant differences test) was carried out. Table 5 shows that firms that are faced with exclusion are typically different from firms inserted in other types of chains in terms of their relatively low mean values in various types of innovative activities. Firms in marketbased and captive chains are different only from firms with exclusion-types of relations with relatively higher mean values of process improvements. Modular value chains are distinguished from all other types of GVC governance by their relatively higher mean values of innovation in design, product, and process development. Modular value chains are also different from market-based chains, as they have higher mean values of innovation in work systems; however, they do not show significantly higher mean values of innovativeness in marketing and branding-innovation activities than those of other types of GVC governance.

What are the overall implications of these findings? First, they indicate that innovative behaviour associated with process upgrading is widespread in Bursa, regardless of the ways in which the chain is governed-by market-based, captive, or modular relations. This is not a surprising outcome, as it is widely acknowledged that the current global reorganisation of the automotive industry is taking place according to a strategy that is designed to leverage suppliers to increase product and process quality, while at the same time cutting costs and meeting higher productivity targets. This forces suppliers into innovative behaviour with regard to process upgrading (Dyker et al, 2003).

However, significant differences emerge when it comes to product upgrading. Here, suppliers operating in modular value chains are in a more favourable position than those operating in other types of chains, as they seem to have upgraded their capabilities and moved into design and product development. However, the results indicate that they may continue to encounter barriers when it comes to moving into marketing and branding-related innovation activities, implying that leading-edge innovation activities remain in the domain of lead firms. It seems that despite the increasing competences of suppliers and the subsequent shift in value chain governance, power asymmetries along the value chain continue to be well protected by lead firms (see also Tokatlı et al, 2008), and lead firms continue to have a major influence on the type of upgrading strategies that are open to their suppliers.

\section{Conclusion}

Building on the GVC perspective in this paper I have provided an account of the shifts in value chain governance and upgrading in the automotive value chain in Bursa, Turkey. One of the main findings is that as suppliers in Bursa have gained competences in design and product development, their customers have turned to modular value chains in sourcing from them. This implies that design and product development are now less confined to the domain of direct suppliers to vehicle manufacturers, and that the consequences of the current reorganisation of the automotive industry have included a further diffusion of design and product-development capabilities among suppliers on the periphery of automotive production, such as those in Bursa. It would appear that Turkish suppliers have managed to build on the opportunities offered by value chain leaders and developed further capabilities, and as a result are likely to be able to command higher prices. 
However, the comparison of the types of GVC governance observed in Bursa in terms of differences in the innovation activities associated with process, product, and functional upgrading indicate that although more and more responsibilities have been passed to Turkish suppliers as they have upgraded their capabilities to include design and product development, suppliers in Bursa continue to encounter barriers when it comes to moving into marketing and branding-related innovation activities. This suggests that cutting-edge innovation activities such as marketing and branding remain with the lead firms, the reason being that as these higher value-added competences are spread to new suppliers, the returns to the lead firms decline, and thus the value of such competences is devalued (see Schrank, 2004, page 125). In addition, the risk of supplier failure is reproduced for higher value-added activities such as marketing and branding, meaning that careful coordination is required (see Humphrey and Schmitz, 2002b). This implies that power asymmetries along the automotive value chain continue to be protected by lead firms, bringing into question the real level of opportunity for upgrading for suppliers on the periphery of GVCs.

This raises an important question: does the increased capability of Turkish suppliers in design and product development imply a reduction of power asymmetries with their customers? Or does it imply that they are encroaching on the core competences of their customers? The findings, together with the impressions of the author from the field study, suggest that the upgrading of Turkish suppliers in design and product development has been less due to Turkish suppliers successfully encroaching on the core competences of their customers, and more to the willingness of lead firms in the automotive industry to relinquish those functions towards competent suppliersdown the hierarchy of the supply chain. By shifting design responsibilities to their suppliers, lead firms are able also to pass the costs and risks of these activities on to them (Follis et al, 2002; Herrigel, 2004; Whitford and Enrietti, 2005). In fact, my impression from the field study is that being innovative in design and product development has become a 'must' for suppliers if they are to become part of the global automotive value chain, as suppliers are forced to adopt this strategy or lose business. This suggests that the shift of design responsibility to suppliers is a means for lead firms to extend their power (see also Tokatli et al, 2008). In this regard, the upgrading of Turkish suppliers in design and product development seems more likely to be a result of lead-firm strategies to peripheralise their traditionally core activities (Schrank, 2004), and hence does not imply that suppliers are encroaching on the core competences of their customers (see also Crewe and Davenport, 1992; Tokatlı et al, 2008). It would seem instead that asymmetric power relations are being maintained in the global automotive industry, and that lead firms continue to have a major influence on the type of upgrading strategies that are open to their suppliers. To date, Turkish suppliers have been employing a strategy to build on opportunities offered by value chain leaders to develop capabilities in such fields as design and product development, through which they are more likely to be able to command higher prices. However, given that these competences are being devalued every day, building on value chain resources may not be sufficient in the long term, and these firms may require more viable strategies if they are to continuously increase their levels of competences. To ensure sustainability, strategic efforts at a firm level to take steps to develop higher value-added capabilities from which they can earn profits will be important. It is only when a company manages to upgrade beyond the requirements of its customers, and earn additional profits, that it can be said to be encroaching on the core competences of its customers.

Obviously, the question remains open as to whether or not Turkish suppliers' development of higher value-added competences is essentially superficial, as is the 
question of how deeply Turkish suppliers are involved in those higher value-added tasks. It is possible that a further study, aimed at a deeper examination of frontier suppliers, would reveal whether or not the competences of Turkish suppliers have truly increased: this is beyond the scope of this particular paper. Although such a study might take us back to the importance of corporate inquiry in shedding light upon the diversity and complexity of value chains, the power relations that characterise them, and upgrading strategies in global value chains, by attempting to identify patterns of chain governance and test the established hypotheses on the relationship between chain governance and upgrading, this paper provides a starting point for understanding how shifts in power asymmetries in value chains and changing opportunities for suppliers in developing economies are linked to recent changes in the organisation of the automotive industry.

Acknowledgements. This paper is part of a larger project part of which was funded by the EU Commission in Framework Programme 6, Priority 7, on 'Citizens and Governance in a Knowledgebased Society', contract no: CIT5-028519. I would like to express my thanks to Professor Mick Dunford, Professor Ayda Eraydın, Professor John Humphrey, and Professor Nick von Tunzelmann for their valuable comments on different versions of the paper, most of which I have incorporated. I also thank the anonymous referees for their valuable comments on earlier versions of the paper. None of these people are responsible for what is or is not said.

\section{References}

Baldwin C, Clark K, 2000 Design Rules (MIT Press, Cambridge, MA)

Barnes J, Kaplinsky R, 2000, "Globalisation and trade policy reform: whither the automobile components sector in South Africa?" Competition and Change 4211 -243

Barnes J, Kaplinsky R, Morris M, 2004, "Industrial policy in developing economies: developing dynamic comparative advantage in the South African automobile sector' Competition and Change $8153-172$

Borrus M, Ernst D, Haggard S (Eds), 2000 International Production Networks in Asia (Routledge, London)

Brusoni S, Prencipe A, 2001, "Unpacking the blackbox of modularity: technologies, products and organisations" Industrial and Corporate Change $10179-205$

Camuffo A, 2002, "Rolling out a "world car": globalisation, outsourcing and modularity in the auto industry", http://imvp.mit.edu/papers/0001/camuffo1.pdf

Crewe I, Davenport E, 1992, "The puppet show: changing buyer-supplier relationships within clothing retailing" Transactions of the Institute of British Geographers, New Series $17183-197$

Dicken P, 2003, "Global production networks in Europe and East Asia: the automobile components industries", WP 7, Global Production Networks, Geography, University of Manchester

Dicken P, Kelly P F, Olds K, Yeung H W-C, 2001, "Chains and networks, territories and scales: towards a relational framework for analysing the global economy" Global Networks 1(2) $89-112$

Dolan C, Humphrey J, 2000, "Governance and trade in fresh vegetables: the impact of UK supermarkets on the African horticulture industry" Journal of Development Studies 37 147-176

Dunford M, 2009, "Globalization failures in a neo-liberal world: the case of Fiat Auto in the 1990s" Geoforum $40145-157$

Dyker D, Nagy A, Spilek H, Stanovnik P, Turk J, Vince P, 2003, “'East' - 'West' networks and their alignment: industrial networks in Hungary and Slovenia" Technovation 23 603-616

Evren Y, 2002, "Supply networks in the car industry: do peripheral economies perform specific tasks? Lessons from the Turkish car industry" International Planning Studies 7 283-302

Follis M, Enrietti A, Whitford J, 2002, "Improving performances at the second tier of the automotive supply chain: Fiat's 'guided improvement' programme in comparative perspective", paper presented to Tenth Gerpisa International Colloquium, 6 - 8 June, Paris, France; http://www.gerpisa.univ-evry.fr/rencontre/10.rencontre/AFollis.pdf

Gereffi G, 1999, "International trade and industrial upgrading in the apparel commodity chain" Journal of International Economics 4837 - 70

Gereffi G, Humphrey J, Sturgeon T, 2005, “The governance of global value chains" Review of International Political Economy 1278 - 104

Herrigel G, 2004, "Emerging strategies and forms of governance in high-wage component manufacturing regions" Industry and Innovation 11(2) 45-79 
Humphrey J, 2000, "Assembler-supplier relations in the auto industry: globalisation and national development" Competition and Change $4245-271$

Humphrey J, 2003a, "Opportunities for SMEs in developing countries to upgrade in a global economy", SEED, WP 43, International Labour Organization, Geneva

Humphrey J, 2003b, "Globalization and supply chain networks: the auto-industry in Brazil and India" Global Networks 3121 - 141

Humphrey J, Memedovic O, 2003, "The global automotive industry value chain: what prospects for upgrading by developing countries", UNIDO Sectoral Studies Series, Vienna

Humphrey J, Schmitz H, 2000, "Governance and upgrading: linking industrial cluster and global value chain research", WP 120, Institute of Development Studies, Brighton

Humphrey J, Schmitz H, 2002a, "How does insertion in global value chains affect upgrading in industrial clusters?" Regional Studies 361017 - 1027

Humphrey J, Schmitz H, 2002b, "Developing country firms in the world economy: governance and upgrading in global value chains", Report61, Institut für Entwicklung und Frieden, University of Duisburg, Duisburg, http://inef.uni-due.de/page/documents/Reports61.pdf

Humphrey J, Schmitz H, 2004, "Chain governance and upgrading: taking stock", in Local Enterprises in the Global Economy: Issues of Governance and Upgrading Ed. H Schmitz (Edward Elgar, Cheltenham, Glos) pp 349-381

Humphrey J, Lecler Y, Salerno M (Eds), 2000 Global Strategies, Local Realities: The Auto Industry in Emerging Market (Macmillan, Basingstoke, Hants)

Istanbul Sanayi Odası, 2002 Otomotiv Sanayii Sektörü Yayın no. 202/4, Cem Ofset Matbaacılık, Istanbul

KOSGEB, 2004 Türk Otomotiv Sanayi'ne Bakış Ekonomik ve Stratejik Araştırmalar Merkez Müdürlüğü, Ankara

Langlois R N, Robertson P L, 1992, "Networks and innovation in a modular system: lessons from the microcomputer and stereo component industries" Research Policy $21297-313$

Layan J, 2000, "The integration of peripheral markets: a comparison of Spain and Mexico", in Global Strategies and Local Realities: The Auto Industry in Emerging Markets Eds J Humphrey, Y Lecler, M S Salerno (Macmillan Press, London) pp 122 - 148, http://www.univ-evry.fr/labos/gerpisa/ actes/31/31-5.pdf

MacDuffie J P, Helper S, 2005, "Collaboration in supply chains: with and without trust", in The Firm as a Collaborative Community: The Reconstruction of Trust in the Knowledge Economy Eds C Heckscher, P S Adler (Oxford University Press, New York) pp 417 - 466

Özatağan G, 2011, Dynamics of value chain governance: increasing supplier competence and changing power relations in the periphery of automotive production-evidence from Bursa, Turkey" European Planning Studies 19 forthcoming

Pietrobelli C, Saliola F, 2008, "Power relationships along the value chain: multinational firms, global buyers and performance of local suppliers" Cambridge Journal of Economics 32 947-962

Posthuma A C, 2005, "Industrial renewal and inter-firm relations in the supply chain of the Brazilian automotive industry", Series on Upgrading in Small Enterprise Clusters and Global Value Chains, International Labour Organization, Geneva

Sadler D, 1998, "Changing inter-firm relations in the European automotive industry: dependence or enhanced autonomy for components producers?" European Urban and Regional Studies 5 $317-328$

Sadler D, 1999, "Internationalization and specialization in the European automotive components sector: implications for the hollowing-out thesis" Regional Studies 33109 - 119

Sako M, 2002, "Modularity and outsourcing: the nature of co-evolution of product architecture and organisation architecture in the global automotive industry", http://gerpisa..univ-evry.fr/rencontre/11.rencontre/papers/Sako.pdf

Schmitz H, 2004, "Globalized localities: introduction", in Local Enterprises in the Global Economy: Issues of Governance and Upgrading Ed H Schmitz (Edward Elgar, Cheltenham, Glos) pp 1 - 19

Schrank A, 2004, "Ready-to-wear development? Foreign investment, technology transfer, and learning by watching in the apparel trade" Social Forces $83123-156$

Shimokawa K, 1999, "New trend for component modules in Japanese" Japanese Automotive News 1 April

Steinfeld E S, 2004, "Chinese enterprise development and the challenge of global integration", in Global Production Networking and Technological Change in East Asia Eds S Yusuf, M A Altaf, K Nabeshima (World Bank, Washington, DC) pp 255-296

Sturgeon T J, 2002, "Modular production networks: a new American model of industrial organisation" Industrial and Corporate Change 11451 - 496 
Sturgeon T J, 2003, "What really goes on in Silicon Valley? Spatial clustering and dispersal in modular production networks" Journal of Economic Geography 3 199-225

Sturgeon T, 2009, "From commodity chains to value chains: interdisciplinary theory building in an age of globalization", in Frontiers of Commodity Chain research Ed. J Bair (Stanford University Press, Stanford, CA) pp $110-135$

Sturgeon T J, Gereffi G, 2009, "Measuring success in the global economy: international trade, industrial upgrading, and business function outsourcing in global value chains" Transnational Corporations $18(2) 1-35$

Sturgeon T J, Lester R K, 2004, “The new global supply-base: challenges for local suppliers in East Asia”, in Global Production Networking and Technological Change in East Asia Eds S Yusuf, A Altaf, K Nabeshima (Oxford University Press, New York) pp 35-87

Sturgeon T, van Biesebroeck J, Gereffi G, 2008, "Value chains, networks and clusters: reframing the global automotive industry" Journal of Economic Geography $8297-321$

Takayasu K, Mori M, 2004, "The global strategies of Japanese vehicle assemblers and the implications for the Thai automobile industry", in Global Production Networking and Technological Change in East Asia Eds S Yusuf, A Altaf, K Nabeshima (Oxford University Press, New York) pp 209-254

Tokatlı N, 2007, "Networks, firms and upgrading within the blue-jeans industry: evidence from Turkey" Global Networks 7(1) $51-68$

Tokatl $\mathrm{N}, 2008$, "Global sourcing: insights form the global clothing industry - the case of Zara, a fast fashion retailer" Journal of Economic Geography 821 - 38

Tokatlı N, Kizilgün O, 2004, "Upgrading in the global clothing industry: Mavi Jeans and the transformation of a Turkish firm from full-package to brand-name manufacturing and retailing" Economic Geography $80221-240$

Tokatlı N, Wrigley N, Kızılgün O, 2008, "Shifting global supply networks and fast fashion: made in Turkey for Marks and Spencer" Global Networks 8(3) $261-280$

Undersecretariat of the Prime Ministry for Foreign Trade, 2005, "Sektörler ltibariyle üretim-Diş Ticaret Ilişkisi ve Rekebet Koşulları", http://www.dtm.gov.tr

Undersecretariat of the Prime Ministry for Foreign Trade, 2007, http://www.dtm.gov.tr/dtmweb/ index.cfm?action $=$ detayrk \&yayin $I D=1116 \&$ icerikID $=1225 \&$ dil $=T R$

Veloso F, Kumar R, 2002, "The automotive supply chain organization: global trends and perspectives", Economics and Research Department (ERD) WP Series 3, Asian Development Bank, Philippines

Whitford J, Enrietti A, 2005, "Surviving the fall of a king: the regional institutional implications of crisis at Fiat Auto" International Journal of Urban and Regional Research 29771 - 795

Yusuf S, 2004, "Competitiveness through technological advances under global production networking", in Global Production Networking and technological Change in East Asia Eds S Yusuf, A Altaf, K Nabeshima (Oxford University Press, New York) pp 1-34 


\section{Appendix}

Measurement of innovation activities associated with process, product, and functional upgrading.

1. Process upgrading

(i) Process improvements: based on the question of the extent to which firms undertake the following activities on a four-point Likert scale: (a) never, (b) sometimes, (c) usually, (d) always:

- increasing production speed,

- cost-price reduction,

- improving delivery speed,

- improving product quality.

A coefficient was calculated as the sum of 'usually' and 'always' answers divided by the number of variables (four).

(ii) Innovation in work systems: based on the extent to which the following activities are applied by the respondent firm, on a three-point Likert scale of: (a) not applied,

(b) to some extent, (c) to a great extent:

- documentation of procedures,

- use of batch trays,

- use of statistical process cards,

- use of travel cards,

- collection and analysis of cell performance data,

- stock control and traceability.

A coefficient was calculated as the sum of 'to a great extent' answers divided by the number of variables (six).

(iii) Innovation in human resource management/organisational systems: based on the question of the extent to which the following activities are applied by the respondent firm, on a three-point Likert scale: (a) not applied, (b) to some extent, (c) to a great extent:

- team working,

- suggestion schemes,

- workplace rotation,

- delegation of responsibility,

- performance reward systems,

- personal development schemes.

A coefficient was calculated as the sum of 'to a great extent' answers divided by the number of variables (six).

(iv) Innovation in technology systems: based on the question of whether or not the respondent firm has invested in the following IT hardware and software:

- process technology:

computer-aided production equipment,

computer-aided design equipment,

statistical process cards,

- logistics technology:

office automation,

automation in design activities,

automation in quality control,

automation of equipment,

automation in information systems for organising production flow,

- quality:

total quality management,

quality-assurance systems,

quality-control methods. 
A coefficient was calculated as the sum of all 'yes' answers divided by the number of variables (eleven).

2. Product upgrading

(v) Product and process development: based on the question of the extent to which the respondent firm undertakes the following activities on a four-point Likert scale:

(a) never, (b) sometimes, (c) usually, (d) always:

- develop new products,

- develop new processes,

- modification of existing products and processes,

- develop new designs.

A coefficient was calculated as the sum of 'usually' and 'always' answers divided by the number of variables (four).

3. Functional upgrading

(vi) marketing and branding: based on the question of the extent to which the respondent firm undertakes marketing and branding activities on a four-point Likert scale:

(a) never, (b) sometimes, (c) usually, (d) always:

A coefficient was calculated as the sum of 'usually' and 'always' answers divided by the number of variables (two). 
Conditions of use. This article may be downloaded from the E\&P website for personal research by members of subscribing organisations. This PDF may not be placed on any website (or other online distribution system) without permission of the publisher. 